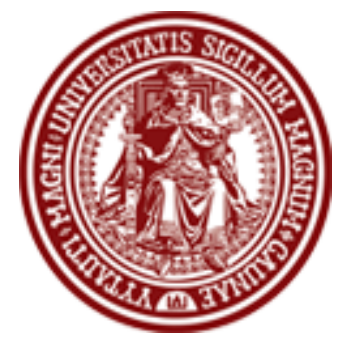

BALTIC JOURNAL OF LAW \& POLITICS

VOLUME 1 (2008)

ISSN 2029-0454

http://www.versita.com/science/law/bjlp

Cit.: Baltic Journal of Law \& Politics 1 (2008): 18-40

DOI: $10.2478 / \mathrm{v} 10076-008-0002-4$

\title{
REFORM OF LITHUANIAN CRIMINAL LAW: TENDENCIES AND PROBLEMS
}

\author{
EDITA GRUODYTÉ \\ Associate Professor; Dr. \\ Vytautas Magnus University Faculty of Law (Lithuania) \\ Contact information \\ Address: S. Daukanto str. 28, LT-44246 Kaunas, Lithuania \\ Phone: 370-37-327873 \\ E-mail address: e.gruodyte@tf.vdu.It
}

Received: October 3, 2008; reviews: 2; accepted: December 5, 2008.

\section{ABSTRACT}

The purpose of the article is to analyze a new Criminal code of the Republic of Lithuania (in force from the $1^{\text {st }}$ of May, 2003), with the aim to highlight its differences from the old one, and, thereby, to discern the most important novelties while discussing their advantages and possible difficulties (if any) in applying the new norms in practice.

The author chooses to investigate only the general part of the criminal code and to analyze, according to the author's opinion, only the most important developments in it, as due to the extent of the article it is impossible to make a detailed analysis of all the novelties in the new criminal code.

The author of the article chooses to analyse classification of offences, diminished responsibility, corporate liability, new factors eliminating criminal liability, reform of penalty system, and extension of possibilities to discharge from criminal liability.

The research reveals that not all discerned novelties are functioning properly and that some critical issues may be indicated, but, in general, the new criminal code is valued as a positive achievement and a great move towards the enhancement of Lithuanian criminal law.

Conclusions of this work, obtained through scientific research, may be used to improve existing criminal code in practice.

\section{KEYWORDS}

Legal reform, criminal code, criminal offence, punishment 


\section{INTRODUCTION}

The creation of the Lithuanian criminal code has quite a long history. The idea to have one's own criminal code was first discussed after Lithuania regained its independence in the year 1990. The same year the Lithuanian Council (the predecessor of the Lithuanian parliament) created a first working group for creation of a criminal code. ${ }^{1}$ The first project was prepared and presented to the Lithuanian parliament only in the year $1996^{2}$, but it was not approved by the parliament, and in 1997 a new group was instituted for the preparation of a criminal code. ${ }^{3}$ Two years later, the Lithuanian government created an expert group for the evaluation of a new project with regard to the development of the Lithuanian criminal code, ${ }^{4}$ which appeared to be successful, and on the $26^{\text {th }}$ of September, 2000, the Lithuanian Parliament enacted new criminal $\operatorname{code}^{5}$, which came into force on the $1^{\text {st }}$ of May, $2003^{6}$. It must be indicated that, irrespective of the long preparation term, during the five years of its functioning, the new code was amended 17 times, the first amendment being done even before the code came into force.

There were two main groups of reasons to create the new code. Formal reasons make the first group - Lithuania never had its own criminal code. Starting from the year 1961, Lithuania had applied the Lithuanian Soviet criminal code, while until the First World War the Russian Statute of punishments of 1903 with adaptations to Lithuanian conditions was in use. ${ }^{7}$ The second group is compiled of practical reasons: after regaining independence in 1990, legal and economic conditions in Lithuania changed and were not reflected in the old criminal code. The need to use the progressive practice of European and other developed countries,

1 Dèl darbo grupiu istatymo projektams rengti sudarymo (1990, no. I-387), available through http://www3.Irs.It/dokpaieska/forma_I.htm (Resolution of the Presidium of the Supreme Council of Lithuania; publication data unidentified); Dèl darbo grupès valstybès kontrolès istatymo projektui rengti sudarymo ir darbo grupés baudžiamojo kodekso projektui rengti papildymo, Official Gazette (1990, no. 28-678) (Resolution of the Presidium of the Supreme Council of the Republic of Lithuania).

2 Dèl Lietuvos Respublikos baudžiamojo kodekso projekto pateikimo Lietuvos Respublikos Seimui (1996, no. 1214), available through http://www3.Irs.It/dokpaieska/forma_I.htm (Resolution of the Government of the Republic of Lithuania; publication data unidentified).

3 Dèl darbo grupes Lietuvos Respublikos baudžiamojo kodekso projektui rengti sudarymo (1997, no. 367), available through http://www3.Irs.It/dokpaieska/forma_I.htm (Decree of the Prime Minister of the Republic of Lithuania; publication data unidentified).

4 Dèl ekspertu komisijos Lietuvos Respublikos baudžiamojo kodekso projektams ivertinti sudarymo (1999, no. 303), available through http://www3.Irs.It/dokpaieska/forma_I.htm (Resolution of the Government of the Republic of Lithuania; publication data unidentified).

5 Lietuvos Respublikos baudžiamojo kodekso patvirtinimo ir isigaliojimo istatymas, Official Gazette (2000, no. 89-2741) (Law of the Seimas of the Republic of Lithuania).

${ }^{6}$ Lietuvos Respublikos baudžiamojo kodekso, patvirtinto $2000 \mathrm{~m}$. rugsejjo 26 d. istatymu Nr. VIII-1968, baudžiamojo proceso kodekso, patvirtinto $2002 \mathrm{~m}$ kovo 14 d. istatymu Nr. IX-785, ir bausmiu vykdymo kodekso, patvirtinto $2002 \mathrm{~m}$. birželio $27 \mathrm{~d}$. istatymu Nr. IX-994, isigaliojimo ir igyvendinimo tvarkos istatymas, Official Gazette (2002, no. 112-4970) (Law of the Seimas of the Republic of Lithuania).

7 Vytautas Piesliakas, "Naujuju baudžiamuju istatymu šaltiniai ir principinès nuostatos" (The sources and principled provisions of new criminal laws), Justitia 4 (1996): 19. 
the need to reform criminal policy, among them - punishments ${ }^{8}$, and to transform obligations from international and regional treaties and agreements into national laws determined necessity of a new code.

Lithuania decided to use a pure codification model, while in most European countries (for example, Greece, Denmark, Sweden, Netherlands) crimes of an international character (drugs, guns, trafficking in human beings, etc.) are criminalized by separate legal acts. In 1995, the Lithuanian Constitutional Court stated that international treaties could not be applied directly in domestic criminal law, but must be transformed into national law, ${ }^{9}$ which means that Lithuania supports a dualistic theory. After ratification of any new international treaty or issuance of the EU legal acts (for example, Council Framework decisions), they are not applied directly, but must be transformed into national law. Such a position of the Lithuanian Constitutional Court was criticized by Lithuanian scientists, ${ }^{10}$ but yet according to Lithuanian scientist Vytautas Piesliakas "the question of direct application of international treaties in criminal law is not simple and there can not be one answer." ${ }^{11}$

The new Lithuanian code, like the previous one, consists of two main parts general and special. However, from the $1^{\text {st }}$ of May 2004 (when Lithuania became a member of the EU) the Lithuanian criminal code was supplemented by an additional section, named Implemented EU Legal acts. In the first part the legislator describes the basic ideas and principles of criminal law, enumerates punishments and principles of their imposition, defines criminal deeds, explains such institutes as conspiracy, stages of crime, circumstances eliminating criminal liability and other details, while the special part is dedicated to the description of specific crimes and possible sanctions. The legislator ranges groups of crimes by their severity. In Lithuania, crimes against humanity and war crimes are given the status of the greatest significance, then crimes against state and democracy are listed, and crimes against human life are in the third place. Such an order of crimes is used in some European countries, for example, in French code. ${ }^{12}$

The aim of the article is to review fundamental changes in Lithuanian criminal law after inaction of the new criminal code, their significance and magnitude to the

\footnotetext{
${ }^{8}$ In Lithuania, like in other countries of the former Soviet Union, the main punishment - imprisonment was considered to be not effective and financially expensive.

${ }^{9}$ Lietuvos Respublikos Konstitucinio Teismo nutarimas, Official Gazette (1995, Nr. 9-199) (Resolution of the Constitutional Court of Lithuania).

${ }^{10}$ For example, see Andrius Nevera, Valstybès baudžiamosios jurisdikcijos principai (Principles of the criminal jurisdiction of the state) (Vilnius: Mykolo Romerio universitetas, 2006), p. 18-23.

${ }_{11}$ Vytautas Piesliakas, Lietuvos baudžiamoji teisè, pirmoji knyga (Criminal law of Lithuania, first book) (Vilnius: Justitia, 2006), p. 27.

12 N. E. Krilova, ed., trans., Уголовный кодекс Франции. Законодательство зарубежных стран (Criminal code of France. Legislature of foreign countries) (Санкт-Петербург: Юридический центр Пресс, 2002), p. 7-34.
} 
development of Lithuanian criminal law and possible hardships while applying them in practise.

Considering the large amount of transformations, the article is limited only to fundamental institutes of the general part of Lithuanian criminal code such as classification of offences, mens rea, corporate offenders, etc.

The author makes the presumption that not every change in the Lithuanian criminal code is entirely affirmative and unambiguously applied in practice.

\section{CLASSIFICATION OF OFFENCES}

As Jean Pradel states, today offences are classified into two groups almost in all criminal codes. ${ }^{13}$ In Lithuania the legislator for the first time provided a definition of criminal deeds and classified them into two big groups: punishable offences, for which imprisonment is not provided as a sanction, and crimes. An example of a punishable offence is the intoxication of a child (article 161). Crimes in reference to fault are divided into two groups: intentional and negligent. The first group is further divided into five groups, and the whole scheme is presented below:

Scheme 1

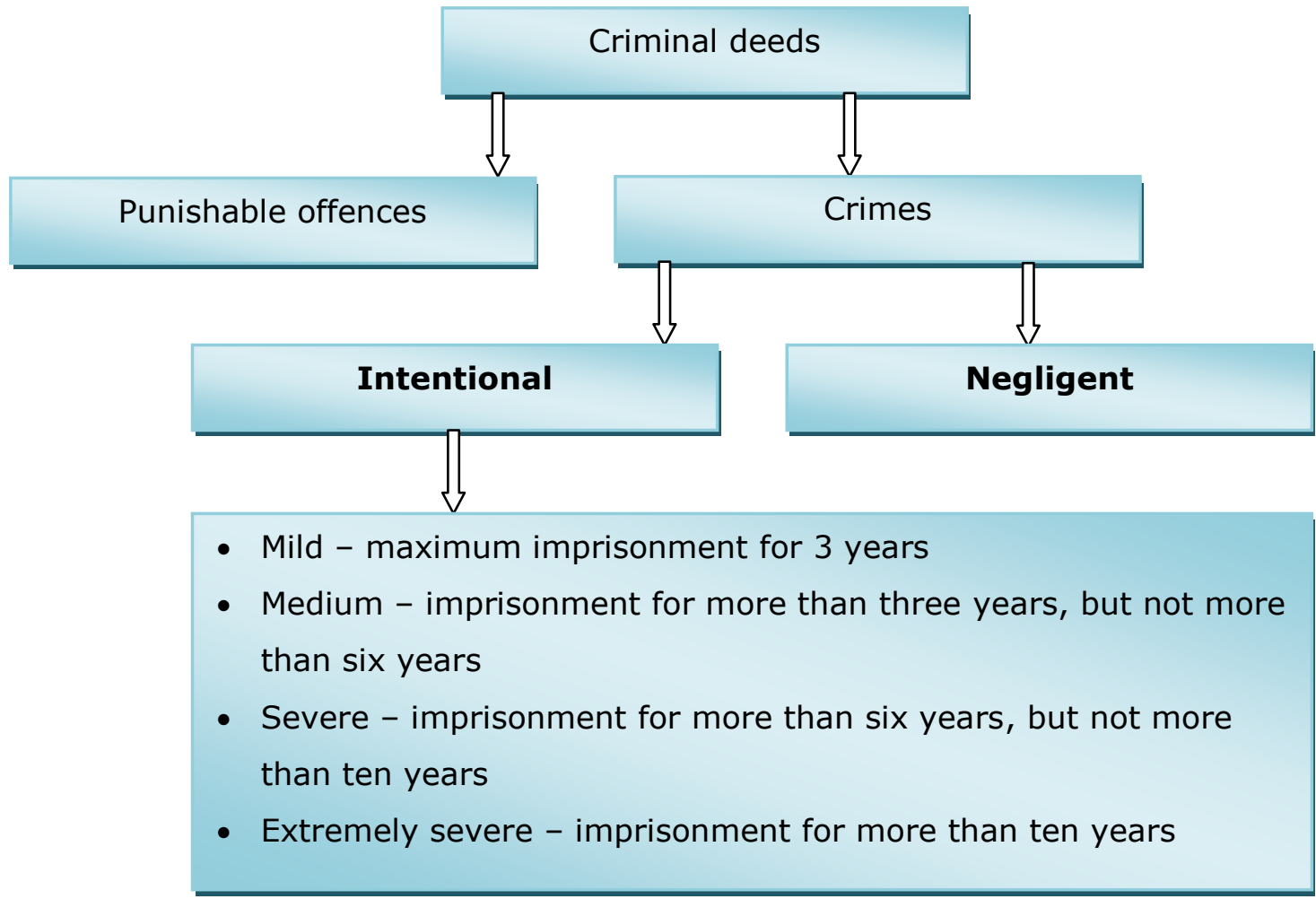

13 Jean Pradel, Lyginamoji baudžiamoji teisè (Comparative criminal law) (Vilnius: Eugrimas, 2001), p. 219. 
Meanwhile crimes in the old criminal code were divided by severity only into two groups - severe crimes and other crimes.

This novelty could be evaluated positively as it brings in more clarity. The criminal code is based on the classification, mentioned above. Starting with criminal deeds up to severe crimes the legislator provides many opportunities to bypass real imprisonment. There is no such possibility foreseen for severe and extremely severe crimes. The criminal deeds are ranged in respect to their severity as well, and adequate sanctions are provided.

The incoherent actions of legislators have to be pointed out as significant drawback: the criminal offence was introduced in order to eliminate existing duplication problem of minor crimes in the criminal code and administrative offences in the administrative code. Yet the problem still exists, as Lithuania is not able to finalize drafting of its new administrative code. For example, the criminal code foresees responsibility for illegal manufacturing, processing, acquiring, possessing, transportation or transfer of small amounts of narcotic drugs and psychotropic substances without having intent to sell or distribute in any other way (article 259, part 2), while in the administrative code there is a provision about responsibility for the illegal acquiring or possessing of small amounts of narcotic drugs and psychotropic substances (article 44, part 1). Two illegal acts - acquiring or possessing of narcotic drugs and psychotropic substances - are identical and cause problems for legal practitioners. The same problem occurs with the norms of public order (article 284, part 2 of criminal code and article 174 of administrative code) - the same behaviour is described as prohibited by two norms, yet there is no real criteria how to delimitate those two norms. Basically practitioners chose the easiest way: according to the article 9, part 2 of the administrative code, administrative responsibility occurs for the offences foreseen in the administrative code, if those offences by their nature do not imply criminal responsibility. In cases when there is provision for the same offence in both codes, practitioners apply the criminal code, and formally they are right. However, the essential question remains: what is the purpose of the existence of the same norm in both codes and why not apply the universally accepted principle in dubio pro reo (all ambiguities and inaccuracies should be interpreted on the behalf of defendant)? Hopefully these problems will be solved by the new administrative code in the nearest future. 


\section{MENS REA (DIMINISHED RESPONSIBILITY)}

The second novelty is related to the psychical status of offender - for the first time the legislator, alongside with insufficient sanity, establishes one more possible state of mind - diminished responsibility, defined as a psychical disorder which is not sufficient to recognize a person insane, but because of which a person could not entirely understand the felonious character of the criminal deed or could not entirely control one's acts ${ }^{14}$. Criminal case $2 \mathrm{k}-325 / 2004^{15}$ can be used as an example. Marius Jukevicius was convicted for murder, yet according to the findings of psychiatric, psychological and addictive substances expertise, he was in a state of frustration and was not capable to entirely understand his actions. The court decided that Marius Juskevicius lacked the mental capacity to understand his own actions and gave him a lesser punishment. The application of diminished responsibility in Lithuania differs from that in common law countries, because in Lithuania state of mind is important when hearing every case with criminal charges, while in common law countries it matters usually only for murder. ${ }^{16}$

The novelty was already criticized by Lithuanian scientists. As justly pointed out be Gintaras Švedas, such a form for legitimizing diminished responsibility is controversial, because a person is not criminally insane but also is not compos mentis (responsible). The given formulation denies a theoretical basis for criminal liability - the elements of criminal offence ${ }^{17}$, because one of the features of subjective side - mens rea of the person - cannot be proved. Gintaras Švedas's suggestion that the psychic status of offender should be defined in the section of the criminal code "Imposition of sanctions"18 is reasonable, because then lawyers are able to implement the aims of the legislator. In other words, in cases when the person is of diminished responsibility there is a possibility to apply lesser sanctions, and if needed to impose medical measures without twisting the classical understanding of the elements of criminal offence.

One should also mention a possibility of problematic practical application there are no clear medical criteria which allows establishing whether the psychical status of the person is diminished. The legislator, when formulating the law, did not oblige the court to obtain a conclusion from experts in every case before making the decision. Meanwhile, the commentary of the criminal code (article 18) says that

\footnotetext{
${ }^{14}$ Lietuvos Respublikos baudžiamasis kodeksas, Official Gazette (2000, no. 89-2741), art. 8 (Criminal Code of the Republic of Lithuania).

${ }^{15}$ State $v$ M.J., Supreme Court of the Republic of Lithuania (2004, no. 2K-325).

${ }^{16}$ Alan Read, Peter Seago, Criminal law, 2d ed. (Sweet and Maxwell, 2002), p. 211.

${ }^{17}$ Object, subject, subjective side, objective side.

18 Gintaras Švedas, Baudžiamosios politikos pagrindai ir tendencijos Lietuvos Respublikoje (Tendencies and foundations of the criminal policy in the Republic of Lithuania) (Vilnius: Teisines informacijos centras, 2006), p. 119-120.
} 
in every case, for the purpose of indication of the degree and intensiveness of the disorder at the moment of the crime, there must be psychiatric expertise assigned $^{19}$. But in the cases of late maturity of the person (what may be also seen as a form of limited responsibility), the court may unanimously decide if the person under 21 is not mature (article 81 of the criminal code). For example, in the case $2 \mathrm{k}-200 / 2004^{20}$, the Lithuanian Highest Court decided to deny the complaint of the convicted person to apply article 81 of the criminal code without consultation with experts on the psychical status of the person involved. The decision was based on the ground that in some cases a person who is more than 18 years old but did not reach 21 , may be treated as minor (the person up to 18 years) depending on his social maturity. Such person could be granted with all graces foreseen for minors. In the case mentioned above the decision was made considering that the convicted person was mature and ignoring the request made by the accused person's attorney to invite to the court the person's parents, teachers, psychologist or sociologist. The decision was based on the factual circumstances of the case: that the crime was planned and organized beforehand, the crime was serious, the convicted person involved other persons, among them - a minor person. The argument here is that court's decision was provided by the legislator and thus legitimate, but such a formulation of a norm leaves a potentiality to use it improperly because no criterion or recommendations on how to identify a person's maturity is provided.

Even more disputable is the decision of the legislator to differentiate consequences for the person of diminished responsibility based on the seriousness of the crime which was committed under certain circumstances: if the person of diminished responsibility made a criminal offence of the extent up to a severe crime, he may be discharged from criminal liability and medical or criminal measures may be applied, or the penalty may be softened. If the person committed a severe or extremely severe crime, he must be punished in accordance with the criminal code but the penalty may be softened. ${ }^{21}$ Such a position of the legislator shows a lack of the understanding of diminished responsibility - if the person has some psychical deviation which is not enough to recognize the person insane, in many cases he needs medical measures which are not directly foreseen as a possibility for the most serious crimes by the current formulation.

19 Gintaras Švedas, ed., Lietuvos Respublikos baudžiamojo kodekso komentaras, bendroji dalis (Commentary of the criminal code of the Republic of Lithuania, general part) (Vilnius: Teisinès informacijos centras, 2004), p. 117.

${ }^{20}$ R.Ž v. State, Supreme Court of the Republic of Lithuania (2004, no. 2k-200).

${ }^{21}$ Lietuvos Respublikos baudžiamasis kodeksas, supra note 14, art. 18. 


\section{EXTENSION OF CORPORATE LIABILITY}

Criminal liability for juridical persons was already introduced in the old criminal code in the end of the year 2002, but was explicated only in the new code. One may say that this is brand new concept as comparison of the same institute in the common law system and in Lithuania reveals how rather reserved this institute is in Lithuania, and how its practical application is not popular. Theoretically criminal liability for a juridical person is projected for 101 out of 241 crimes (about 42 percent of all crimes), which is a rather big number as for now ${ }^{22}$. Basically it is foreseen for intellectual property and computer crimes, financial crimes such as falsification of money, avoiding the payment of taxes, fraudulent accounting, smuggling, for some banking crimes, for several crimes to private life, for fraud crime, for destruction of property and others. Great discussions arose after legislator's decision to enact criminal liability for juridical persons for some sexual crimes such as raping of minor person, sexual violence of minor person, but we do not have practical application of those norms at this time.

Like in some other countries, Lithuania uses two theories: vicarious liability (respondeat superior) and identification doctrines. The first one means that liability to juridical person may arise if almost any person, working in juridical person or acting for the juridical person (for example, employee) commits some criminal act. According to the second theory, only acts committed by the persons defined as responsible ones (such as general manager, manager, board members and others) raise criminal liability. ${ }^{23}$ In our country the legislator chose both types - because, according to the $2^{\text {nd }}$ part of the article 20 of Lithuanian criminal code, only a limited circle of persons could be charged as acting in the name of a juridical person:

- Persons who have the right to represent a juridical person (usually general manager or manager, sometimes a chairman of a board); or

- Persons who make decisions in the name of a juridical person; or

- Persons who control the activities of a juridical person.

But the third part of the aforementioned article foresees responsibility also to employees or authorized persons if the crime was committed because of a lack of control of the aforementioned persons.

There are several exceptions - the government, a municipality and their institutions or agencies, and international public organisations cannot be liable. In all cases mens rea must be identified; in terms of punishment there is no strict

\footnotetext{
22 The criminal code as valid for the 1st July 2008, because criminal liability for juridical persons is expanding.

${ }_{23}$ Gintautas Šulija, "Juridiniu asmenu baudžiamosios atsakomybès samprata ir taikymo problemos Lietuvoje" (Conception and issues of the application of the criminal responsibility of legal persons in Lithuania), Jurisprudencija 41 (2003): 91-105.
} 
liability in the Lithuanian criminal code. Possible penalties include: a fine (from one $M^{24}$ (36 euro) to ten thousand MGL (362025 euro), restriction of juridical person activity (from one to five years), and dissolution of the juridical person. The court also has the right to announce the inflicted punishment through media. The basic principle in the new code is that there is only one penalty for one crime, but in the author's opinion, providing the court with an opportunity to announce the penalty publicly violates that principle. A juridical person gets two penalties in the case of a fine and publicity, because it not only pays money, but also ruins its reputation and sustains losses due to publicity.

The basic problem is that the legislator did not define special criteria for the imposition of penalties, and the outcomes may be really very different depending on the company. For example, a crime was committed by a company that possesses capital of 2896 euro (standard capital for closed stock company). The court punishes it with a fine of 5000 MGL (181012.5 euro). The basic principle in the criminal code though is that the court must give the average punishment if there are no aggravating or palliative circumstances. It is obvious that such a company most likely will be forced into bankruptcy. Another example: a crime is committed by a huge company with capital that reaches a million or several million euro. The penalty would have to be the same if the same conditions as in the first case apply, but the question then is whether justice was carried out. In author's opinion, the legislator must define different criteria for the punishment of juridical persons, and they must be presented clearly in legal act. For example, our legislator may use the principle of European Union where offences of competition are defined with the limitation that fines cannot exceed 10 percent of company's yearly turnover ${ }^{25}$. The US Code also establishes some principles defining limitations of fines in cases where alternative fines are based on gain or loss; the amount of fine depends on the gain obtained or the damage done. No fine twice as high as the damage done or the gain obtained from criminal activity can be set. ${ }^{26}$

Lithuanian scientists expressed the opinion that in order for penalties to achieve their projected goal, and in order to avoid negative social financial consequences while implementing existing penalties, the Lithuanian criminal code should be supplemented with additional penalties such as deprivation of a right to get benefit or support from the government; temporary or permanent deprivation of a right to carry out commercial activity; application of court supervision and

\footnotetext{
${ }^{24}$ That is, so-called, minimal amount of money, necessary for living; this amount is periodically declared by Lithuanian government.

${ }^{25}$ Council Regulation (EEC) No 4064/89 of 21 December 1989 on the control of concentrations between undertakings, Official Journal (L 257, 21.9.1990), art. 14.

${ }^{26}$ US Code collection, Title 18, Sec. 3571, http://www.law.cornell.edu/uscode (accessed September 3, 2008).
} 
others. ${ }^{27}$ Such an opinion conforms to the recommendations of the $\mathrm{EU}^{28}$ and the practice in other developed countries (like France or the USA). Existing penalties do not ensure that aims of the criminal liability as such and penalties are reached as the remaining two punishments (except fines) - restriction of activity or dissolution of juridical person - are punishments to be handled with high sensitivity, and their negative consequences may impact the whole society or even change the economical situation of the country. The other problematic aspect - criminal liability for a juridical person is applied very rarely and, according to the opinion of D. Soloveičikas, because such a conception is foreign to Lithuanian mentality, it is introduced in our criminal code while trying to implement our regional and international obligations, but not developed culturally as in common law countries ${ }^{29}$.

\section{EXTENSION OF FACTORS, ELIMINATING CRIMINAL LIABILITY}

While before the year of 2003 there were only three alternative conditions eliminating criminal liability: self defense, necessity, detention (stoppage) of a criminal, the new criminal code establishes five supplementary ones: implementation of special tasks approved by legal authority, performance of professional functions, execution of order, justifiable professional or economic risk, and scientific experiment. It has to be pointed out that these new factors are not applied in practice, except implementation of special tasks. However, author supports a change because it makes at least a theoretically clear distinction between legal and illegal actions. The person can be more certain about criminality of one or other action or behaviour, while earlier a person was formally always subject to punishment if he committed acts causing damage to the things protected by the criminal code, yet in practice it could not be justifiable and was not applied.

\section{REFORM OF PENALTIES SYSTEM}

Fundamental reform in Lithuanian criminal law was accomplished by reforming the penalties system, first of all their types, than their imposition principles, the extension of opportunities in certain cases to correct criminals without the imposition of real punishment, making a clear distinction among offenders under 18 and recidivists. In order to evaluate the advantages of the new

\footnotetext{
27 Deividas Soloveičikas, Juridiniu asmenu baudžiamoji atsakomybè, lyginamieji aspektai (Criminal responsibility of legal persons, comparative aspects) (Vilnius: Justitia, 2006), p. 194-195.

28 2002/629/JHA: Council Framework Decision of 19 July 2002 on combating trafficking in human beings, Official Journal (J L 203, 1.8.2002), art. 5.

${ }^{29}$ Deividas Soloveičikas, supra note 27, p. 160.
} 
criminal code the author decided to look to such evaluation criteria: sanctions and their practical application, while applying the new and the old criminal codes, number of incarcerated persons, and the suspension of penalty prosecution.

\subsection{TYPES OF SANCTIONS AND PROSECUTION TRENDS}

In the old criminal code of Lithuania there were only four sanctions: fine, imprisonment, life imprisonment and corrective labour without imprisonment. The new criminal code foresees eight sanctions for crimes (deprivation of public rights; deprivation of a right to perform certain work or to engage in some activity; public works; fine; restriction of liberty; arrest; imprisonment; life imprisonment) and six sanctions for criminal offences (except imprisonment or life imprisonment).

The first table shows that the most widely used sanction in practice was imprisonment and it constituted from 38 to 47 percent of all sanctions. In practice the importance of imprisonment was twice higher, because as we see from the first table about half of all punishments were postponed. In the old criminal code only two punishments could have been postponed - imprisonment or corrective labour. The latter one was applied rather rarely, so in general the number of postponed punishments has to be added to the number of imprisonments, and then the total number of imprisonment becomes much higher (about 80 percent).

PENALTIES INFLICTED TO CONVICTED PERSONS IN LITHUANIA IN 1998-2002 ${ }^{30}$

Table 1

\begin{tabular}{|c|c|c|c|c|c|}
\hline Punishment & 1998 & 1999 & 2000 & 2001 & 2002 \\
\hline $\begin{array}{l}\text { Convicted } \\
\text { persons } \\
\text { (numbers) }\end{array}$ & 19536 & 19672 & 20680 & 20915 & 19890 \\
\hline $\begin{array}{l}\text { For } 100 \quad 000 \\
\text { inhabitants }\end{array}$ & 548 & 556 & 589 & 600 & 572 \\
\hline $\begin{array}{l}\text { Imprisonment } \\
\text { (number) }\end{array}$ & 7523 & 7457 & 9717 & 9287 & 8669 \\
\hline$\%$ & 38,5 & 37,9 & 47 & 44,4 & 43,6 \\
\hline $\begin{array}{l}\text { Postponed } \\
\text { sanction } \\
\text { (numbers) }\end{array}$ & 10576 & 10503 & 6969 & 8033 & 7144 \\
\hline$\%$ & 54,1 & 53,4 & 33,7 & 38,4 & 35,9 \\
\hline
\end{tabular}

${ }^{30}$ Data is taken from the Center for Crime Prevention in Lithuania, see at http://www.nplc.It. 


\begin{tabular}{|l|l|l|l|l|l|}
\hline $\begin{array}{l}\text { Corrective } \\
\text { labour }\end{array}$ & 676 & 866 & 590 & 1040 & 833 \\
\hline$\%$ & 7,7 & 9,6 & 5,5 & 8,8 & 6,9 \\
\hline Fine & 610 & 679 & 501 & 1473 & 2628 \\
\hline$\%$ & 6.9 & 7,5 & 4,6 & 12,5 & 21,6 \\
\hline
\end{tabular}

As one could see, imprisonment and fine remain the main punishments in the application of the new criminal code but new tendencies are already reflected, too. A rather important part in the punishment scale is allotted for two other punishments: restriction of liberty (which is rapidly increasing in the last two years), and arrest (slight decrease in the last two years). Great importance is imposed on fines - in the previous year they composed almost one third of all sanctions. In foreign countries implementing a balanced criminal policy, fines constitute from 30 to 70 percent of all imposed sanctions ${ }^{31}$ and the new Lithuanian criminal code also reflect that positive feature. The remaining new punishments are not very popular, but it does not make them useless: they are to be applied only for specific crimes, and there are not many crimes placed in such categories. It is often possible to choose from two or three alternative sanctions, and the court has more discretion to act.

PENALTIES INFLICTED TO CONVICTED PERSONS IN LITHUANIA IN 2003-200732

Table 2

\begin{tabular}{|l|c|c|c|c|c|}
\hline Punishment & 2003 & 2004 & 2005 & 2006 & 2007 \\
\hline $\begin{array}{l}\text { Convicted persons } \\
\text { (number) }\end{array}$ & 17555 & 17882 & 16007 & 14717 & 14057 \\
\hline For 100000 inhabitants & 507 & 519 & 467 & 432 & 415 \\
\hline $\begin{array}{l}\text { Postponed sanction } \\
\text { (number) }\end{array}$ & 5413 & 5726 & 2557 & 2447 & 2304 \\
\hline Postponed sanction \% & 30,8 & 32,0 & 16,0 & 16,6 & 16,4 \\
\hline $\begin{array}{l}\text { Life imprisonment } \\
\text { (number) }\end{array}$ & 9 & 6 & 8 & 6 & 7 \\
\hline$\%$ & 0,08 & 0,03 & 0,05 & 0,04 & 0,05 \\
\hline $\begin{array}{l}\text { Imprisonment } \\
\text { (number) }\end{array}$ & 10874 & 8928 & 7786 & 6467 & 6679 \\
\% & 61,9 & 49,9 & 48,6 & 43,9 & 47,5 \\
\hline
\end{tabular}

${ }^{31}$ Gintaras Švedas, Laisvès atėmimo bausmè: baudžiamosios politikos, baudžiamieji teisiniai ir vykdymo aspektai (Punishment of life imprisonment: aspects of criminal policy, legality and implementation) (Vilnius: Teisinès informacijos centras, 2003), p. 48.

${ }^{32}$ Data is taken from the Center for Crime Prevention in Lithuania, see at http://www.nplc.lt. 


\begin{tabular}{|lccccc|}
\hline $\begin{array}{l}\text { Arrest } \\
\text { (number) }\end{array}$ & 1566 & 2879 & 1681 & 1185 & 1106 \\
$\%$ & 8,9 & 16,1 & 10,5 & 8,1 & 7,9 \\
\hline $\begin{array}{l}\text { Restriction of liberty } \\
\text { (number) } \\
\%\end{array}$ & 490 & 962 & 1558 & 1752 & 1788 \\
\hline $\begin{array}{l}\text { Fine } \\
\text { (number) }\end{array}$ & 2,8 & 5,4 & 9,7 & 11,9 & 12,7 \\
\% & 3651 & 4238 & 4359 & 4474 & 4613 \\
\hline $\begin{array}{l}\text { Public works } \\
\text { (number) }\end{array}$ & 20,8 & 23,7 & 27,2 & 30,4 & 32,8 \\
$\%$ & 916 & 819 & 569 & 470 & 272 \\
\hline $\begin{array}{l}\text { Deprivation of right } \\
\text { to work some job or }\end{array}$ & 5,2 & 4,6 & 3,6 & 3,2 & 1,9 \\
engage in some activity & 45 & 49 & 35 & 39 & 61 \\
(number) & & & & & \\
\% & 0,3 & 0,3 & 0,2 & 0,3 & 0,4 \\
\hline $\begin{array}{l}\text { Deprivation of public } \\
\text { rights (number) }\end{array}$ & 4 & 1 & 11 & 4 & 7 \\
$\%$ & 0,02 & 0,01 & 0,07 & 0,03 & 0,05 \\
\hline
\end{tabular}

As table 2 shows, the situation in Lithuania is improving. If in 1994 only one percent of prisoners were sentenced to less than one year of imprisonment, so in 2003 such percentage is already eight times higher. But we see also a different tendency emerging - twice as many prisoners were sentenced to more than 10 years in 2003 in comparison to the number in 1994. This could be determined by possibly the increasing number of serious crimes and also by the increased strictness of penalties for some crimes such like crimes involving narcotic substances. The data in tables 2 and 3 confirm predictions that new rules in the new criminal code for imposing the sanction of imprisonment will decrease the application of this sanction in practice but will prolong its average ${ }^{33}$.

LENGTH OF THE SENTENCE IN LITHUANIA IN 1994 AND IN 2003 IN PERCENTAGE ${ }^{34}$

Table 3

\begin{tabular}{|l|l|l|l|l|l|}
\hline & $<1$ year & $1-3$ years & $3-5$ years & $5-10$ years & 10 years and $>$ \\
\hline 1994 & 1 & 35 & 34 & 25 & 5 \\
\hline 2003 & 8,3 & 31,2 & 24 & 23,8 & 12,6 \\
\hline
\end{tabular}

${ }^{33}$ Gintaras Švedas, supra note 18, p. 198.

${ }^{34}$ Data is taken from the Center for Crime Prevention in Lithuania, see at http://www.nplc.lt. 
It is rather difficult to compare Lithuania with other countries because of diversifications but looking to the average numbers in the table 4 the following conclusion could be done: Lithuania rarely applies the longest term punishment (10 years and more), while the popularity of a 1- to 3-year term is possibly too high.

LENGTH OF THE SENTENCE IN SOME EU COUNTRIES IN 2005 IN PERCENTAGE ${ }^{35}$

Table 4

\begin{tabular}{|l|l|l|l|l|l|}
\hline Country & $<1$ year & $1-3$ years & $3-5$ years & $5-10$ years & 10 years and $>$ \\
\hline Austria & 23,5 & 37,4 & 17,5 & 11,2 & 7,8 \\
\hline Belgium & 2,6 & 13,0 & 25,2 & 34,7 & 19,9 \\
\hline Estonia & 9,7 & 26,2 & 24,0 & 28,0 & 11,1 \\
\hline Finland & 35,3 & 35,8 & 13,4 & 8,6 & 1,0 \\
\hline France & 27,7 & 22,9 & 11,8 & 14,6 & 21,5 \\
\hline Germany & 41,7 & 20,1 & 25,3 & 8,3 & 1,6 \\
\hline Greece & 6,9 & 5,3 & 15,3 & 28,1 & 32,8 \\
\hline Italy & 8,7 & 21,8 & 23,3 & 23,2 & 19,8 \\
\hline Lithuania & $\mathbf{1 0 , 5}$ & $\mathbf{3 3 , 5}$ & $\mathbf{2 2 , 0}$ & $\mathbf{1 1 , 5}$ & $\mathbf{1 , 3}$ \\
\hline $\begin{array}{l}\text { Northern } \\
\text { Ireland }\end{array}$ & 10,6 & 29,3 & 17,4 & 17,9 & 9,3 \\
\hline Norway & 42,7 & 27,4 & 10,8 & 11,8 & 7,3 \\
\hline Portugal & 5,6 & 12,5 & 21,7 & 38,9 & 17,7 \\
\hline Scotland & 20,3 & 19,1 & 16,2 & 21,6 & 4,0 \\
\hline Sweden & 23,9 & 33,5 & 16,4 & 17,6 & 6,1 \\
\hline Average & $\mathbf{1 9 , 3}$ & $\mathbf{2 4}$ & $\mathbf{1 8 , 6}$ & $\mathbf{1 8 , 2}$ & $\mathbf{1 1 , 5}$ \\
\hline
\end{tabular}

It is interesting to compare sentence length in USA; as table 5 illustrates, the average sentence is rather strict - almost five years of imprisonment.

AVERAGE LENGTH OF PRISON SENTENCES IMPOSED BY OFFENCE IN 2001-2002 IN USA ${ }^{36}$

Table 5

\begin{tabular}{|l|l|l|}
\hline $\begin{array}{l}\text { Most serious offence of } \\
\text { conviction }\end{array}$ & $\begin{array}{l}\text { Average sentence length } \\
\text { in months }\end{array}$ & $\begin{array}{l}\text { Average sentence length } \\
\text { in years }\end{array}$ \\
\hline All offences & 57,1 & 4,76 \\
\hline Felonies & 58,4 & 4,87 \\
\hline
\end{tabular}

${ }^{35}$ Vytautas Piesliakas, Lietuvos baudžiamoji teise, antroji knyga (Criminal law of Lithuania, second book) (Vilnius: Justitia, 2008), p. 166-167.

${ }^{36}$ Data is taken from Bureau of Justice Statistics, Compendium of Federal Justice Statistics (2002), see at www.ojp.usdoj.gov/bjs/pub/pdf/cfjs0205.pdf. 


\begin{tabular}{|l|l|l|}
\hline Violent offences & 88,5 & 7,37 \\
\hline Property offences & 25 & 2,08 \\
\hline Drug offences & 76 & 6,33 \\
\hline Public-order offences & 38,5 & 3,2 \\
\hline Weapon offences & 83,9 & 6,99 \\
\hline Immigration offences & 27,9 & 2,32 \\
\hline Misdemeanours & 9,8 & 0,82 \\
\hline
\end{tabular}

\subsection{NUMBER OF INCARCERATED PERSONS}

Other important data reflecting criminal policy is the number of prisoners per 100000 inhabitants.

NUMBER OF PRISONERS PER 100000 INHABITANTS IN 1990-1994 37

Table 6

\begin{tabular}{|c|c|c|}
\hline Number & Country & Number for 100000 inhabitants \\
\hline 1. & Germany & 38 \\
\hline 2. & Slovenia & 47 \\
\hline 3. & Austria & 81 \\
\hline 4. & Slovakia & 92 \\
\hline 5. & N.Ireland & 98 \\
\hline 6. & Hungary & 99 \\
\hline 7. & England & 101 \\
\hline 8. & Czechia & 108 \\
\hline 9. & Latvia & 115 \\
\hline 10. & Portugal & 134 \\
\hline 11. & Finland & 143 \\
\hline 12. & Lithuania & 188 \\
\hline 13. & Switzerland (1991) & 194 \\
\hline 14. & Russia & 205 \\
\hline 15. & Italy & 213 \\
\hline 16. & Scotland & 220 \\
\hline 17. & Norway & 271 \\
\hline
\end{tabular}

${ }^{37}$ Kristina Kangaspunta, Matti Jousen, Natalia Ollus, eds., Crime and criminal justice systems in Europe and North America 1990-1994 (Monsey, New York: Criminal Justice Press, 1998), p. 58. 


\begin{tabular}{|l|l|l|}
\hline 18. & Netherlands & 286 \\
\hline 19. & Denmark & 289 \\
\hline 20. & Turkey & 394 \\
\hline 21. & USA & $389^{38}$ \\
\hline
\end{tabular}

NUMBER OF PRISONERS SERVING IMPRISONMENT TERM PER 100000 INHABITANTS (INCLUDES PERSONS WITH IMPOSED CUSTODY) ${ }^{39}$

Table 7

\begin{tabular}{|c|c|c|c|c|c|c|c|}
\hline No. & Country & & 96 & & 004 & & 005 \\
\hline & & $\begin{array}{l}\text { Absolute } \\
\text { number }\end{array}$ & $\begin{array}{l}100 \quad 000 \\
\text { inhabitants }\end{array}$ & $\begin{array}{l}\text { Absolute } \\
\text { number }\end{array}$ & $\begin{array}{l}100 \quad 000 \\
\text { inhabitants }\end{array}$ & $\begin{array}{l}\text { Absolute } \\
\text { number }\end{array}$ & $\begin{array}{l}100 \quad 000 \\
\text { inhabitants }\end{array}$ \\
\hline 1. & Norway & 2290 & 52 & 2975 & 65 & 3097 & 67,2 \\
\hline 2. & Finland & 2952 & 57,8 & 3446 & 66 & 3823 & 73 \\
\hline 3. & Denmark & 3203 & 61 & 3762 & 69,7 & 4132 & 76,4 \\
\hline 4. & Sweden & 5768 & 65 & 7332 & 81,7 & 7054 & 78,3 \\
\hline 5. & Portugal & 14177 & 140 & 13563 & 129 & 12889 & 122,4 \\
\hline 6. & Germany & 67677 & 82,6 & 79676 & 96,5 & 48992 & 95,7 \\
\hline 7. & Slovenia & 614 & 31 & 1126 & 56,4 & 1132 & 56,7 \\
\hline 8. & $\begin{array}{l}\text { England/ } \\
\text { Wales }\end{array}$ & 537 & 106,8 & 74488 & 140,4 & 76190 & 142,7 \\
\hline 9. & Switzerland & 6047 & 85,4 & 6021 & 81,8 & 6111 & 82,4 \\
\hline 10. & Czechia & 20860 & 202 & 18160 & 178 & 19052 & 186,4 \\
\hline 11. & Slovakia & 7734 & 144 & 9504 & 176,7 & 9289 & 172,5 \\
\hline 12. & Belgium & 7656 & 75,6 & 9245 & 88 & 9371 & 89,7 \\
\hline 13. & Italy & 48545 & 85 & 56090 & 96,9 & 59649 & 102 \\
\hline 14. & Hungary & 12923 & 129 & 16410 & 162,2 & 16394 & 162,4 \\
\hline 15. & Austria & 6778 & 84 & 8700 & 106 & 8767 & 106,8 \\
\hline 16. & Lithuania & 11980 & 323 & 7827 & 227,1 & 7993 & 233,4 \\
\hline 17. & Estonia & 4745 & 300 & 4565 & 337,9 & 4410 & 327,4 \\
\hline 18. & Scotia & 5916 & 101 & 6885 & 135,6 & 6795 & 133,4 \\
\hline 19. & Latvia & 10161 & 405 & 7731 & 333,3 & 7228 & 313,4 \\
\hline 20. & Russia & 1047997 & 713 & 787900 & 548 & 823672 & 576,8 \\
\hline
\end{tabular}

Comparing number of prisoners per 100000 inhabitants in various countries, in 1994, Lithuania was ranking somewhere in the middle of the list, but the fifth table reveals that imprisonment in Lithuania is still very popular and only three countries - Russia, Estonia and Latvia - score higher than Lithuania. Even though the data from the Lithuania crime prevention centre shows lightly lower numbers

\footnotetext{
38 Data is taken from Bureau of Justice Statistics, Correctional Populations in the United States (1997), see at www.ojp.usdoj.gov/bjs/pub/pdf/cpus.97.pdf.

${ }^{39}$ Vytautas Piesliakas, supra note 35, p. 165.
} 
(table 6), the number of prisoners in Lithuania on average is twice higher than in the Europe. These tendencies show that Lithuania should revise its criminal policy.

NUMBER OF ARRESTED AND CONVICTED PERSONS IN CORRECTIONAL INSTITUTIONS IN THE YEAR 199-2007 IN LITHUANIA ${ }^{40}$

Table 8

\begin{tabular}{|c|c|c|c|c|c|c|c|c|c|}
\hline & $\begin{array}{c}1999 \\
12\end{array}$ & $\begin{array}{c}2000 \\
12\end{array}$ & $\begin{array}{c}2001 \\
12\end{array}$ & $\begin{array}{c}2002 \\
12\end{array}$ & $\begin{array}{c}2003 \\
12\end{array}$ & $\begin{array}{c}2004 \\
12\end{array}$ & $\begin{array}{c}2005 \\
12\end{array}$ & $\begin{array}{c}2006 \\
12\end{array}$ & $\begin{array}{c}2007 \\
12\end{array}$ \\
\hline $\begin{array}{l}\text { Inquisitorial } \\
\text { isolators }\end{array}$ & 2.959 & 2.823 & 2.535 & 2.669 & 2.550 & & & & \\
\hline Total number & 14.584 & 14.412 & 9.516 & 11.566 & 11.070 & 8.063 & 8.125 & 8.137 & 8.079 \\
\hline Convicted & - & - & - & - & 9.414 & 6.701 & 6.841 & 7.010 & 7.082 \\
\hline $\begin{array}{l}\text { \% for } \\
100000 \\
\text { inhabitants }^{41}\end{array}$ & 314 & 332 & 200 & 257 & 273 & 196 & 201 & 207 & 210 \\
\hline Arrested & - & - & - & - & 1.656 & 1.362 & 1.284 & 1.127 & 997 \\
\hline
\end{tabular}

\subsection{SOME OTHER COMPARATIVE ASPECTS OF CRIMINAL POLICY}

The new criminal code is more flexible. For example, if arrest is imposed for not more than 45 days, a prisoner may serve his sentence during weekends. Even six punishments do not deprive liberty while they establish some restrictions of it, which may be better than imprisonment in certain cases. But there may be some problems because of the structural composition of the criminal code. First of all, the punishment of deprivation of public rights is not foreseen in a special part of criminal code. It becomes unclear when a court imposes such a sentence. Legislators only mentioned the possibility to impose such a punishment when a crime is committed trespassing public rights, and the sanction is composed of multiple punishments where one of the punishments is deprivation of a right to perform certain work or to engage in a certain activity. Secondly, usually sanction for one crime provides several alternative punishments (for example, article 178: Theft. One who stole property is punishable by public works, or by fine, or by restriction of freedom, or by imprisonment to three years). As Gintaras Švedas notes, a new criminal code shows the consistency of the legislator while constructing sanctions, because all sanctions are alternative. However, a detailed

\footnotetext{
${ }^{40}$ Data is taken from the Center for Crime Prevention in Lithuania, see at http://www.nplc.It.

${ }^{41}$ Data is counted by the author, taking the data on the amount of the inhabitants from the Center for Crime Prevention in Lithuania and deducting percentage amount from the total number the amount of inquisitorial isolators.
} 
analysis of the variants shows what the legislator overdid in some cases: the alternative of an entire seven sanctions is foreseen once, and other nine variants of sanctions are foreseen only two or three times in the criminal code ${ }^{42}$.

The legislator leaves rather much discretion for the court to decide what kind of punishment to impose but some basic principles are provided. For example, if the person is convicted for the first time for the criminal deed up to a severe crime, punishment without imprisonment should be imposed; if a recidivist is convicted for an intentional crime the court should sentence him to imprisonment. Special rules are foreseen for application of sanctions for minor (persons under 18), and etc.

\section{EXPANSION OF POSSIBILITIES TO DISCHARGE FROM CRIMINAL}

\section{LIABILITY}

The new Lithuanian criminal code foresees more possibilities to discharge the person from criminal liability, and the rules are balanced much better: privileges and exceptions are provided if the criminal deed is not of the high level of seriousness (i.e. neither a severe nor extremely severe crime is committed). The author decided to look more deeply only into two conditions: discharge under guarantee, and the reconciliation of perpetrator and victim.

There are several conditions that must be fulfilled in order to use the guarantee mechanism:

- a request of a person whom the court trusts;

- the crime was committed for the first time and;

- the accused confesses his fault and regrets his conduct and ;

- harm was eliminated or at least partially compensated, or the convict is obliged to compensate for damage if any was done;

- it is reasonable to think that the convict will entirely compensate or eliminate the harm, will obey laws, and will not commit new crimes.

The first and the last conditions are subjective because they depend on the judge's opinion, while the other are objective.

The guarantor may be the offender's parents, close relatives or other persons. The term of sponsion is from one to three years. The basic problem is that court is handed too much power. Court may decide whether to use a sponsion with bail or without bail. The legislator did not say anything about the sum of bail or the conditions under which it should be arranged, so the court has complete freedom of action.

\footnotetext{
${ }^{42}$ Gintaras Švedas, supra note 18, p. 159-160.
} 
The second institute was started back in 1993, but was extended in the new criminal code. It includes the possibility to discharge from criminal liability if perpetrator and victim reconcile. The institute is very well known in Anglo-Saxon law. In American law it is a contract among victim and culprit. The institute also exists in some European countries - for example Spain, but in many West European countries (France, Finland, Austria, Germany, Netherlands and etc.) such an institute does not exist. Instead, they have some analogy - the possibility to discharge from criminal liability for certain crimes if a culprit compensates damages. ${ }^{43}$ Such an institute helps to decrease the cost of criminal procedure. In 2000 the institute was used for 4130 cases in preliminary investigation stage, while in 2001 - 4101, in 2002 - 4167, in January-March of 2003 - 1027 persons, and in court proceedings - for 926 in 1998, for 830 in 1999 and for 765 in 2000. ${ }^{44}$ If a person made a punishable offence, negligent crime, intentional soft or medium crime, he may be discharged from criminal liability if:

- one confesses that he made a crime;

- one compensated or eliminated the harm done to a physical or juridical person in his own will, or agreed for the compensation or elimination of the harm;

- reconciled with the aggrieved party or with a representative or juridical person or governmental institution;

- it is reasonable to think that one will not commit new crimes.

If court applies this mechanism, it must be done imposing one condition- an offender should not commit new intentional crimes in the period of one year. Otherwise the decision to discharge from criminal liability would expire and the court would decide on the criminal responsibility for both the previously made and new criminal deeds.

\section{CONCLUSIONS}

1. Lithuania's new criminal code is a very important achievement of the Lithuanian nation, because it is the first national criminal code that reflects the tendencies of the new criminal policy of developed countries.

2. The first important achievement, among others, is a definition of a criminal deed and its classification, which makes the criminal code very clear and

\footnotetext{
43 Agnè Baranskaitė, "Kaltininko ir nukentėjusiojo susitaikymo institutas Lietuvos Respublikos baudžiamajame kodekse: istorinis lyginamasis aspektas" (Institute of the reconciliation of perpetrator and victim in the Criminal code of the Republic of Lithuania: historical comparative aspect) Jurisprudencija 45 (2003): 59.

${ }_{44}$ Data is taken from the Center for Crime Prevention in Lithuania, see at http://www.nplc.It/stat/atas/ird/bs/bs.htm.
} 
easy to use since other conditions depend on the kind of the committed criminal deed. The introduction of the criminal offence partially solved the problem of duplication of some deeds in criminal and administrative codes, but other existing problems hopefully will be solved in a new administrative code.

3. The legislator introduces the diminished responsibility status of an offender, which helps legal institutions to implement justice. However, the chosen form and differentiation of consequences based on the seriousness of the crime raise some doubts.

4. The extension of liability for a juridical person is a positive innovation, yet outcomes may be very different and sometimes even destructive. There is no guidance as to the extent of punishments, and only three possible sanctions for juridical persons are foreseen. Additional sanctions are needed, such as deprivation of the right to be engaged in commercial activity, application of court supervision, deprivation of the right to get benefit or support from the government, especially since such additional sanctions are also recommended by EU acts.

5. In the new criminal code the legislator invents five more factors eliminating criminal liability - implementation of special tasks approved by legal authority, performance of professional functions, execution of order, justifiable professional or economic risk, and scientific experiment. The innovation is timely and based on previous problems, but it is difficult to say whether it will not raise any problems in practice because only one of the factors was applied in practice so far.

6. The basic achievement of the new criminal code is the reform of penalty system; additional punishments and some new principles are introduced in order to prevent the extended usage of imprisonment. This strategy is partially fruitful - the percentage of individuals given the sanction of imprisonment has decreased from 80 percent to 50-60 percent, while new sanctions - restriction of liberty, arrest, and public works are also applied in practice. But the numbers of prisoners in correctional institutions are twice higher than in the rest of the EU countries except Estonia and Latvia.

7. The two new institutes for the discharge from criminal liability - sponsion and reconciliation between a perpetrator and victim are very useful as they help decrease the costs of criminal procedure. In addition, the offender is given one more chance to return to normal life. 


\section{BIBLIOGRAPHY}

1. Baranskaitè, Agnè. "Kaltininko ir nukentèjusiojo susitaikymo institutas Lietuvos Respublikos baudžiamajame kodekse: istorinis lyginamasis aspektas" (Institute of the reconciliation of perpetrator and victim in the Criminal code of the Republic of Lithuania: historical comparative aspect). Jurisprudencija 45 (2003): 59-69.

2. Kangaspunta, Kristina, Matti Jousen, and Nattali Ollus, eds. Crime and criminal justice systems in Europe and North America 1990-1994. Monsey, New York: Criminal Justice Press, 1998.

3. Nevera, Andrius. Valstybès baudžiamosios jurisdikcijos principai (Principles of the criminal jurisdiction of the state). Vilnius: Mykolo Romerio universitetas, 2006.

4. Piesliakas, Vytautas. Lietuvos baudžiamoji teisè. Antroji knyga (Criminal law of Lithuania. Second book). Vilnius: Justitia, 2008.

5. Piesliakas, Vytautas. Lietuvos baudžiamoji teisè. Pirmoji knyga (Criminal law of Lithuania. First book). Vilnius: Justitia, 2006.

6. Piesliakas, Vytautas. "Naujuju baudžiamuju istatymu šaltiniai ir principinès nuostatos" (The sources and principled provisions of new criminal laws). Justitia 4 (1996): 19-20.

7. Pradel, Jean. Lyginamoji baudžiamoji teisé (Comparative criminal law). Vilnius: Eugrimas, 2001.

8. Read, Alan and Peter Seago. Criminal law. 2nd ed. Sweet and Maxwell, 2002.

9. Soloveičikas, Deividas. Juridiniu asmeny baudžiamoji atsakomybè. Lyginamieji aspektai (Criminal responsibility of legal persons. Comparative aspects). Vilnius: Justitia, 2006.

10. Švedas, Gintaras. Baudžiamosios politikos pagrindai ir tendencijos Lietuvos Respublikoje (Tendencies and foundations of the criminal policy in the Republic of Lithuania). Vilnius: Teisinès informacijos centras, 2006.

11. Švedas, Gintaras, ed. Lietuvos Respublikos baudžiamojo kodekso komentaras. Bendroji dalis (Commentary of the criminal code of the Republic of Lithuania. General part). Vilnius: Teisinès informacijos centras, 2004.

12. Švedas, Gintaras. Laisvès atèmimo bausmè: baudžiamosios politikos, baudžiamieji teisiniai ir vykdymo aspektai (Punishment of life imprisonment: aspects of criminal policy, legality and implementation). Vilnius: Teisinès informacijos centras, 2003.

13. Šulija, Gintautas. "Juridiniu asmenu baudžiamosios atsakomybès samprata ir taikymo problemos Lietuvoje" (Conception and issues of the application of the 
criminal responsibility of legal persons in Lithuania). Jurisprudencija 41 (2003): 91-105.

\section{LEGAL REFERENCES}

1. 2002/629/JHA: Council Framework Decision of 19 July 2002 on combating trafficking in human beings. Official Journal, J L 203, 1.8.2002.

2. Council Regulation (EEC) No 4064/89 of 21 December 1989 on the control of concentrations between undertakings. Official Journal, L 257, 21.9.1990.

3. Dèl darbo grupés Lietuvos Respublikos baudžiamojo kodekso projektui rengti sudarymo. 1997, no. 367 // available through http://www3.Irs.It/dokpaieska/forma_I.htm (Decree of the Prime Minister of the Republic of Lithuania; publication data unidentified).

4. Dèl darbo grupès valstybès kontrolès istatymo projektui rengti sudarymo ir darbo grupès baudžiamojo kodekso projektui rengti papildymo. Official Gazette, 1990, no. 28-678 (Resolution of the Presidium of the Supreme Council of the Republic of Lithuania).

5. Dèl darbo grupiu istatymo projektams rengti sudarymo. 1990, no. I-387 // available through http://www3.Irs.It/dokpaieska/forma_I.htm (Resolution of the Presidium of the Supreme Council of Lithuania; publication data unidentified).

6. Lietuvos Respublikos baudžiamasis kodeksas. Official Gazette, 2000, no. 892741 (Criminal Code of the Republic of Lithuania).

7. Dèl ekspertu komisijos Lietuvos Respublikos baudžiamojo kodekso projektams ¿vertinti sudarymo. 1999, no. 303 // available through http://www3.Irs.It/dokpaieska/forma_I.htm (Resolution of the Government of the Republic of Lithuania; publication data unidentified).

8. Dél Lietuvos Respublikos baudžiamojo kodekso projekto pateikimo Lietuvos Respublikos Seimui. 1996, no. 1214 // available through http://www3.Irs.It/dokpaieska/forma_I.htm (Resolution of the Government of the Republic of Lithuania; publication data unidentified).

9. Lietuvos Respublikos baudžiamojo kodekso patvirtinimo ir isigaliojimo istatymas. Official Gazette, 2000, no. 89-2741 (Law of the Seimas of the Republic of Lithuania).

10. Lietuvos Respublikos baudžiamojo kodekso, patvirtinto $2000 \mathrm{~m}$. rugsejjo $26 \mathrm{~d}$. istatymu Nr. VIII-1968, baudžiamojo proceso kodekso, patvirtinto $2002 \mathrm{~m}$ kovo $14 \mathrm{~d}$. istatymu Nr. IX-785, ir bausmiu vykdymo kodekso, patvirtinto $2002 \mathrm{~m}$. birželio 27 d. istatymu Nr. IX-994, isigaliojimo ir igyvendinimo 
tvarkos istatymas. Official Gazette, 2002, no. 112-4970 (Law of the Seimas of the Republic of Lithuania).

11. Lietuvos Respublikos Konstitucinio Teismo nutarimas. Official Gazette, 1995, no.9-199 (Resolution of the Constitutional Court of Lithuania).

12. Krilova, N.E., ed., trans. Уголовный кодекс Франции. Законодательство зарубежных стран (Criminal code of France. Legislature of foreign countries). Санкт-Петербург: Юридический центр Пресс, 2002.

13. R.Ž v. State. Supreme Court of the Republic of Lithuania, 2004, no. 2k-200.

14. State $v$ M.J. Supreme Court of the Republic of Lithuania, 2004, no. 2K-325.

15. US Code collection // http://www.law.cornell.edu/uscode (accessed September 3, 2008). 